\title{
TRIM5 wt Allele
}

National Cancer Institute

\section{Source}

National Cancer Institute. TRIM5 wt Allele. NCI Thesaurus. Code C98162.

Human TRIM5 wild-type allele is located in the vicinity of 11 p15 and is approximately 275 $\mathrm{kb}$ in length. This allele, which encodes tripartite motif-containing protein 5 , is involved in the negative regulation of viral infection. 